\title{
SPRAWOZDANIA
}

\section{SPRAWOZDANIE Z KONFERENCJI „USTRÓJ W OKRESIE ROZKWITU CZY KRYZYSU? PARALELE: RZYM RepublikańsKi a UE”}

W dniu 5 kwietnia 2018 r., w Auli Schumana Auditorium Maximum Uniwersytetu Kardynała Stefana Wyszyńskiego w Warszawie (UKSW), odbyła się konferencja, której tematem był „Ustrój w okresie rozkwitu czy kryzysu? Paralele: Rzym Republikański a UE”. Patronat nad konferencją objął Pan Michał Marusik, poseł do Parlamentu Europejskiego, wiceprzewodniczący grupy Europa Narodów i Wolności.

Obrady poprowadziła Profesor Renata Kamińska z Wydziału Prawa i Administracji UKSW. Profesor Anna Tarwacka, prodziekan WPIA UKSW w imieniu władz Wydziału powitała prelegentów i gości, dziękując im za przybycie, a następnie zdefiniowała zakres przedmiotowy konferencji.

Pan Poseł Michał Marusik wprowadził słuchaczy w omawianą problematykę porównując UE do okrętu i wskazując, że losy państw członkowskich są nierozerwalnie powiązane z losem całości. Prelegent koncentrował swoje wystąpienie na podmiotowości państw członkowskich, która jest wartością, jednocześnie krytykując nadmierną unifikację w ramach UE. Zwrócił uwagę, że UE może spotkać taki koniec jak starożytny Rzym. Postawił tezę, że, być może, w przypadku niekorzystnych okoliczności, Polska powinna opuścić wspólnotowe struktury.

Profesor Jan Zabłocki w wystąpieniu Zasady sprawowania urzędów a doświadczenie rządzacych przypomniał legendę o powstaniu Rzymu, opowiadając o Romulusie, Remusie i wilczycy. Zwrócił uwagę na pełnię władzy Romulusa oraz istotę władzy królewskiej w dalszym etapie monarchii. Następnie porównał władzę królewską do władzy konsularnej w republikańskim Rzymie. Scharakteryzował system urzędniczy 
w republice rzymskiej, a także praktykę funkcjonowania zgromadzeń. Omówił zasady: kadencyjności, kolegialności i nieodpłatności urzędów, jak również vacatio oraz incompatibilitas. Poruszył także problematykę cursus honorum, wskazując, że urzędnicy rzymscy mieli możliwość zdobywania doświadczenia na poszczególnych szczeblach władzy, zaczynając nawet wcześniej od tirocinium fori u boku ojca.

Prof. Anna Tarwacka przedstawiła referat zatytułowany Harmonia czy dysharmonia? Zaburzenia równowagi ustrojowej jako przyczyna upadku republikańskiego Rzymu. Przybliżyła triadę ustrojową Arystotelesa, wyodrębniając ustroje czyste i zwyrodniałe. Przytoczyła postać Polibiusza, który badał ustrój republikańskiego Rzymu, próbując go sklasyfikować i scharakteryzować, jednocześnie dostrzegając jego równowagę ustrojową. Opisała specyfikę poszczególnych urzędów republikańskiego Rzymu. Prelegentka sformułowała tezę, jakoby schyłek funkcjonowania tego ustroju przyniósł narastające odstępstwa od reguły równowagi systemowej w Rzymie. Następnie, w pierwszym etapie budowy cesarstwa, Oktawian instrumentalnie posłużył się urzędami republikańskimi, żeby skumulować władzę wokół własnej osoby. Efektem tego była sytuacja, w której ustroju republikańskiego nie dało się już w żaden sposób przywrócić.

Marszałek Marek Jurek, poseł do PE swój referat zatytułowany Europa: solidarność czy autodestrukcja? Polska a kryzys UE zaczął od memento związanego z upadkiem Rzymu. Identyfikację kryzysu UE rozpoczął od zjawiska Brexitu, które było uznawane w PE za rzecz szokującą, wręcz niemożliwą. Następnie przeszedł do kryzysu migracyjnego, utożsamiając go z kryzysem terrorystycznym (bezpieczeństwa), aby potem przejść do sytuacji ustrojowej na Węgrzech i groźbie uruchomienia art. 7 wobec tego państwa. Marszałek Marek Jurek stwierdził nieefektywność, brak współpracy i uznawania opozycji w strukturach UE, uznając że kryzys jest bardzo poważny. Poseł stwierdził, że odpowiedzią ze strony Unii na te problemy stało się wzmocnienie integracji w obrębie państw członkowskich, w tym zacieśnienie unii gospodarczo-walutowej, a także koncept poboru podatków bezpośrednio do kasy UE. Przywołał paralelę, zgodnie z którą XIX-wieczna zachodnioeuropejska „wolność polityczna” była zestawiana ze wschodnioeuropejską „wolnością 
od polityki”. Poseł stwierdził, że KE przejmuję władzę w obrębie UE w sposób sprytny, w drodze kumulacji kompetencji, przywołując m.in. koncept likwidacji stanowiska przewodniczącego Rady Europejskiej na rzecz jednego przedstawiciela UE w postaci szefa Komisji Europejskiej. Następnie poseł przywołał pomysły stworzenia jednolitej armii europejskiej. Marek Jurek stwierdził, że tzw. imigracjonizm stanowi kolejny przejaw kryzysu UE, któremu na pierwszej linii przeciwstawiały się Węgry. Skonstatował, że mimo wszelkich zaniechań strukturalnych UE, istnieją pewne symptomy reakcji, jak np. wybory parlamentarne we Włoszech i w Austrii. Moralny kształt Europy skręca jego zdaniem w niewłaściwą stronę, czemu np. przeciwstawia się sprawująca unijną prezydencję Bułgaria. Marek Jurek podkreślił, że należy brać pod uwagę proces, a nie mechanizm, a generalnym celem jest zatrzymanie procesu „imperializacji” UE. Przez działalność państw członkowskich ma zostać wymuszona afirmacja suwerenności państw, a Europa powinna zacząć wracać do swojej kulturowej, duchowej i moralnej tradycji, a współpraca europejska powinna zostać podjęta kosztem mechanizmu destrukcji Europy narodowej. Po wystąpieniu miała miejsce krótka dyskusja.

W drugiej sesji Pan dr Tymoteusz Zych z WPIA UKSW wygłosił referat Rodzina a państwo w starożytnym Rzymie i współczesnej Europie. Na wstępie prelegent stwierdził, że dla Rzymian rodzina była podstawową wspólnotą społeczną, a także ogniskiem wolności i nadzieją na przyszłość. Oktawian doprowadził do uchwalenia tzw. ustaw małżeńskich, dotyczących m.in. na karania za cudzołóstwo. Dr Zych powołał się na Tacyta, który twierdził, że zmiany te nie spotkały się z większym uznaniem ani nie przyniosły większych efektów. Prelegent przywołał poglądy Fryderyka Engelsa na temat rodziny, który postulował jej eliminację z życia społecznego, gdyż ogranicza ona wolność człowieka. Na tym rozwiązaniu wzorowali się częściowo bolszewicy. Rolę rodziny zaczęło następnie przejmować państwo. Dr Zych przywołał przykłady i statystyki dotyczące odbierania przez państwo dzieci rodzicom. Prelegent zilustrował różnego rodzaju patologie w systemie opieki społecznej/ rodzinnej. Autor przeciwstawiał rodzinę w Rzymie do tej, która funkcjonuje w świecie współczesnym. Dr Zych, powołując się na Tocqueville’a, 
skonstatował, że nadmierny pęd w kierunku indywidualizmu prowadzi do zatracenia podstawowych funkcji rodziny.

Prof. dr hab. Grzegorz Kucharczyk w wystapieniu zatytułowanym Dlaczego upadł Rzym, dlaczego upada UE? Stwierdził, że w historii Rzymu można dostrzec analogie do czasów współczesnych, dlatego można nazwać ją klasyczną. Prelegent przytoczył bitwę pod Adrianopolem z 378 r., która stanowi dla niego pewną cenzurę zapoczątkowującą rozpad Cesarstwa Rzymskiego. W 407 r. legiony rzymskie opuściły Brytanię, co stanowiło symbol dekadencji tego państwa - można dostrzec tutaj analogie względem Brexitu. Prof. Kucharczyk przybliżył pojęcie pietas, które stanowi rdzeń funkcjonowania państwa. Ulegało ono erozji, czemu starał się, bezskutecznie, zapobiec cesarz Oktawian August. Autor zauważył, że depopulacja w Rzymie była najsilniejsza tam, gdzie chrześcijaństwo było najsłabsze - a więc na prowincjach i na zachodzie. Prof. Kucharczyk postawił tezę, iż UE upada ze względu na próbę tworzenia pewnej wizji ładu cywilizacyjnego, gdzie jakiekolwiek odniesienie do religii jest programowo wymazywane. Przykładem jest preambuła do Konstytucji dla Europy, odrzuconej w 2005 r., gdzie nie została uwzględniona Invocatio Dei. UE stanowi więc dla prelegenta konstrukt skazany na porażkę ze względu na zatracenie wspomnianej pietas. Kryzys Rzymu polegał na tym, że proporcjonalnie było coraz mniej Rzymian, a kryzys UE polega na tym, że jest coraz mniej Europejczyków. Po wystąpieniu miała miejsce krótka dyskusja z udziałem prelegenta.

Trzecią sesję otworzył referat Dra Krzysztofa Kawęckiego, Polityczna i cywilizacyjno-kulturowe uwarunkowania kryzysu starożytnego Rzymu i Unii Europejskiej. Przedmiotem wystąpienia prelegenta była koncepcja federalistyczna, która stanowi fundament współczesnej UE. Dr Kawęcki uważa, że u źródeł kryzysu UE znajduje się proces destrukcji państw narodowych, który następuje obok rozwiązań traktatowo-prawnych. Autor opisał genezę koncepcji federalistycznej, począwszy od poglądów ks. Luigi Sturzo, przez koncepcje integracyjne z II wojny światowej, po idee powojenne, koncentrując się na ideach Roberta Schumana oraz Jeana Monneta. Prelegent zwrócił uwagę, że koncepcje federalistyczne chadeków i socjaldemokratów zasadniczo nie różnią się od siebie. Karta 
Praw Podstawowych z 2000 r. nie zawierała odniesień do chrześcijańskiego dorobku Europy. Dr Kawęcki zaznaczył, że nowe postmodernistyczne rozwiązania prawne nie mają nic wspólnego z chrześcijańską kulturą prawną. Prelegent uznał, że współczesne czasy przypominają nieco okres starożytnego Rzymu poprzez kulturowy kosmopolityzm czy najazdy zewnętrzne pod postacią barbarzyńców, a obecnie muzułmanów. UE charakteryzuje również relatywizm. Wyrazem kryzysu jest dezintegracja porządku prawnego i politycznego państw członkowskich, co również przypominało sytuację ówczesnego Rzymu. Innym problemem jest laicyzacja społeczeństw wielokulturowych. Klasa polityczna nie chce z tym walczyć, ponieważ wyznaje tożsame zasady. Laickie państwo doprowadziło do wyparcia życia chrześcijańskiego. Spadek populacji wpływa na proces starzenia się społeczeństw Europy, podczas gdy w przypadku muzułmańskiej ludności napływowej obserwuje się trend odwrotny. Federalistyczny model prowadzi zatem do stanu acywilizacyjnego wspólnoty europejskiej. Dla prelegenta odpowiedzią na te problemy powinien być chrześcijański uniwersalizm.

Następnie Wojciech Kubań przedstawił referat na temat Uniwersalny Cykl Życia Imperium według John'a Glubb'a. Prelegent relacjonował konkluzje Glubb'a dotyczące porównania imperiów, których okresy trwania to zwykle ok. 250 lat. Transport i metody walki nie miały znaczenia dla momentu upadku, nie był istotny także system polityczny. Schemat upadku był bardzo podobny. Pan Kubań scharakteryzował kolejno następujące po sobie fazy: zrywu, zdobywców, gospodarcza, obfitości, intelektu, dekadencji. W kontekście europejskim zasady te miały charakter podobnie wielopłaszczyznowy. Prelegent zwrócił uwagę na receptę sukcesu Szwajcarii, która opiera się na zasadach: subsydiarności, inkluzywności, trzeźwej solidarności. Polska powinna dążyć do modelu szwajcarskiego, opierając się na konkurencyjności.

Ostatni referat na temat To nie kryzys, to rezultat wygłosił Profesor Robert Gwiazdowski. Prelegent podkreślił, że powyższy temat odnosi się nie tylko do systemu gospodarczego, ale i politycznego, jednocześnie odwołując się do słów Stefana Kisielewskiego. Wyróżnił wewnętrzne i zewnętrzne czynniki kryzysu, spośród których te drugie uznał za ważniejsze. Błędne koncepcje natury ludzkiej legły u podłoża stworzenia 
instrumentów instytucjonalnych, które prowadziły do kryzysu. Człowiek ma naturę społeczną i potrzebuje państwa i prawa do tego, aby broniło jego wolności. Prawo stanowione we współczesnych państwach narodowych koncentruje się na tym, jak należy ograniczyć wolność i własność, co stanowi przejaw kryzysu, gdyż nie służy temu, do czego zostało ustanowione. W ustroju republikańskim racjonalna mniejszość miała większy wpływ na rządy niż emocjonalna większość w demokracji. Politycy odwołują się zatem do emocji, a nie do rozumu. Ustrój prawno-polityczny jest wadliwy - zarówno w Polsce, jak i w UE. Należy pomyśleć nad jego właściwą reformą.

Po wystąpieniach odbyła się dłuższa dyskusja z udziałem publiczności i trzech prelegentów, a następnie Profesor Renata Kamińska oficjalnie podsumowała konferencję i podziękowała wszystkim uczestnikom.

Jan Sobiech*

* Uniwersytet Kardynała Stefana Wyszyńskiego w Warszawie 